\title{
Evaluating the interrelation of a retailer's relationship efforts and consumers' attitudes and behaviour
}

Received (in revised form): 12th October, 2005

\section{Chiung-Ju Liang}

is an associate professor of the Department of Business Administration, National Taiwan University of Science and Technology. Her research focuses on relationship marketing, consumer loyalty and strategic marketing. Her papers have been published in the Journal of Services Research, and are forthcoming in the Journal of Financial Services Marketing, The Services Industries Journal and the Journal of Services Research.

\section{Wen-Hung Wang}

is an assistant professor of the Department of Business Administration, Chung-Kuo Institute of Technology. Wen-Hung has also written for the Journal of Services Research, with forthcoming papers scheduled for publication in the Journal of Financial Services Marketing, The Services Industries Journal and the Journal of Services Research.

Chiung-Ju Liang Department of Business Administration, National Taiwan University of Science and Technology, 43, Sec. 4, Keelung Road, Taipei, 106,

Taiwan, ROC

Tel: +886 (02) 27333141 ext. 6507

Fax: +886 (02) 27376744

E-mail:

cjliang0412@yahoo.com.tw

\begin{abstract}
This study develops and empirically tests a model for examining the impact of different relationship efforts made by a retailer (financial bonding, social bonding and structural bonding) on key relationship marketing outcomes (trust, relationship commitment and behavioural loyalty). A study in information services industry was conducted based on samples drawn from XYZ Company, the largest information education services institute in Taiwan. Standard error of the mean results indicate that retailers undertaking relationship efforts to loyal consumers can positively affect these consumers' attitudes and behaviour. In addition, the findings suggest that information services with different attributes need different kinds and levels of relationship efforts. Consequently, managers and employees of retail companies need to be trained, motivated and rewarded for making relationship efforts to regular consumers.
\end{abstract}

Keywords: relationship efforts, trust, commitment, consumer relationship management, LISREL

\section{INTRODUCTION}

Providing qualified service is considered an essential strategy for success and survival in today's competitive environment. ${ }^{1-4}$ As most retail markets have reached maturity and have difficulties differentiating themselves based on merchandise selection only, ${ }^{5,6}$ retailers are increasingly obliged to seek out products, processes and technologies to increase consumer value. ${ }^{7-9}$ In general, however, retailers have little knowledge on the types of consumer value drivers on which they should focus. ${ }^{10}$ Bendapudi and Berry ${ }^{11}$ and Bitner $^{12}$ conceptualised what some of these drivers might be, but no systematic, empirical investigation has been reported. In particular, research pertaining to relationship marketing in consumer markets has advanced little. $^{13}$ 
In general, marketing literature has focused on product and service efforts as drivers of total consumer value, to the neglect of relationship efforts. ${ }^{14-17}$

Additionally, research has shown that service quality enhancement and relationship marketing ${ }^{18-20}$ are appropriate strategies for commercial banks and other service institutes. What is more, Kimball $^{21}$ has suggested that, 'relationship- and product-oriented strategies are diametrically opposed to one another, with relationship-oriented banks striving to consolidate scattered consumer accounts, and product-oriented banks chipping away at competitors' relationship-oriented consumers'. Therefore, the present study defines and operationalises three types of relationship efforts and empirically validates their impact on consumers' trust, relationship commitment and behavioural loyalty.

Relationship efforts increasingly become important as a source of consumer value. First, consumers' quality expectations related to consuming products and services have risen. ${ }^{22}$ Secondly, retailers are increasingly competing with one another on the basis of the same or highly comparable marketing tactics and strategies. Thirdly, retailers are faced with new challenges of the marketing environment, such as blurring boundaries between markets or industries, an increasing fragmentation of markets and shorter product lifecycles. ${ }^{23}$ Furthermore, several authors have argued that when companies offer similarly high levels of product or service quality, the delivery of relationship benefits becomes an important means of gaining competitive advantage. ${ }^{24-26}$

This paper aims to test the correlation between relationship efforts and relationship outcomes (consumer attitudes and behaviour). The underlying concept of this paper is that if relationship effort relates to behavioural outcome, then evidence of its impact on consumers' behavioural responses (ie trust, commitment and behavioural loyalty) should be detectable. The sequences of relationship efforts on consumer behavioural intentions can be viewed as signals of retention or defection and are desirable for monitoring. With that in mind, the objectives are fourfold:

1 To summarise existing evidence about the behavioural sequences of relationship efforts and relationship outcomes at the individual consumer level.

2 To offer a conceptual model of the impact of relationship efforts on relationship marketing and particular behaviours that signal whether consumers remain with or defect from the company.

3 To report the results of an empirical study examining the correlation between relationship efforts and consumers' behavioural intentions (ie trust, commitment and loyalty).

4 To suggest a research agenda whereby information about individual-level behavioural sequences of relationship efforts can be monitored and linked to relationship outcomes to provide ongoing evidence of the impact of relationship bonding tactics on behavioural loyalty.

\section{CONCEPTUAL FRAMEWORK AND HYPOTHESES}

A tally with the study of De Wulf and Odekerken-Schroder ${ }^{27}$ provided the idea behind the present model. They defined a relationship effort as, 'any effort that is actively made by a retailer towards a consumer, that is intended to contribute to the consumer's perceived consumer value above and beyond the core product and/or service efforts received, ${ }^{28}$ and that can only be perceived by the consumer 
after continued exchange with the retailer'. Generally speaking, a relationship effort refers to an effort that is actively made by a retailer. For example, a 'convenience benefit,' resulting from the fact that a consumer gradually learns where products are located in a convenience store, is not regarded as an actively provided effort because the convenience store has no active role in its development. ${ }^{29}$ Specifically, Fontenot and Wilson $^{30}$ and Frenzen and Davis ${ }^{31}$ argued that product/service efforts and relationship efforts offer two distinct and independent sources of value.

Product/service efforts correspond to what Parasuraman et al. ${ }^{32}$ referred to as 'transaction-specific efforts' dealing with the exchange object and process surrounding one particular transaction. In their framework, transaction-specific efforts consist of product quality, price and service quality (often measured by the SERVQUAL scales, including tangibles, reliability, empathy, responsiveness and assurance as dimensions). This study focuses upon relationship-specific efforts beyond transaction-specific efforts as an additional means of competitive differentiation. ${ }^{33}$ Relationship efforts go beyond a single exchange, focusing upon a range of transactions that are interrelated to past and future exchanges. ${ }^{34}$

Parasuraman $^{35}$ indicated that, 'consumers may need to accumulate considerable experience with a product before being able to accurately assess the extent to which a company's offering helps them realise their higher-order, abstract goals'. In addition, Gwinner et al. ${ }^{36}$ stated that, although consumers may report to receive relational benefits and believe these benefits are important, they may not always be aware of their existence in early stages of a relationship and may not have quantified their value yet. Therefore, De Wulf and Odekerken-Schroder ${ }^{37}$ suggest that it is inevitable that consumers are able to perceive a relationship effort for applying effective relationship outcomes. Consequently, the definition presented here stresses that relationship efforts can only be perceived after a continued exchange with the retailer.

To determine the extent to which relationship marketing efforts contribute to consumers' relationship outcomes, the study assesses the interconnection between trust and three relationship marketing tactics (financial bonding, social bonding and structural bonding), constructs that differ from the four relationship marketing tactics of De Wulf et al. $^{38}$ (tangible rewards, direct mail, preferential treatment and interpersonal communication).

Figure 1 represents a conceptual model that depicts the behavioural sequence of trust and commitment as intervening variables between relationship bonding tactics and behavioural loyalty. This portion is at the level of the individual consumer and proposes that relationship efforts and consumers' trust and commitment are positively related with respect to information education services. The second portion of the model proposes that consumers' trust and commitment, and behavioural loyalty are positively related. Thus, relationship efforts, trust and commitment are determinants for whether a consumer ultimately remains with or defects from a company. The specific hypotheses are presented in the following sections.

\section{RELATIONSHIP BONDING TACTICS}

Bonds are the psychological, emotional, economic or physical attachments in a relationship that are fostered by association and interaction, and serve to bind parties together under relational 


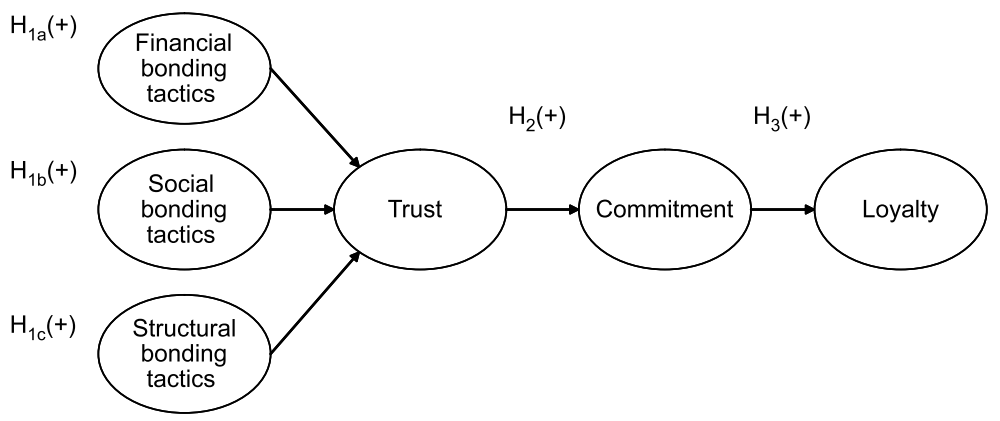

Note: Numbers are standardised path coefficients

Figure 1 Conceptual framework

exchange. ${ }^{39,40}$ While previous researchers conceptualised two types of bonds: structural and social, ${ }^{41,42}$ Smith $^{43}$ proposed that functional bonds also serve to bind parties to a relationship. Based on this, De Wulf et al. ${ }^{44}$ distinguish between four types of relationship marketing tactics distributed across level one relationship marketing; tangible rewards and level two relationship marketing: direct mail; preferential treatment; and interpersonal communication.

Berry and Parasuraman ${ }^{45}$ however, divide the way retailers use to stimulate consumer behavioural loyalty into three levels: financial, social and structural bonding tactics; many researchers also brought up similar relationship marketing classification levels. ${ }^{46,47}$ Thus, this paper will continue to use the position of Berry and Parasuraman, ${ }^{48}$ as detailed below.

\section{Financial bonding tactics}

Financial bonding tactics are a kind of bond stimulating consumers' consumption motivation and acquiring consumers' loyalty by using price decision, such as price discounts, higher interest rate, etc. This kind of integration emphasises the pricing function of marketing components. As it is easy to be emulated by competitors, it is not an easily sustained competitive advantage. Additionally, this kind of relationship bonding tactic is somewhat similar to functional bonds provided by Smith, ${ }^{49}$ and thus it is the multiplicity of economic, performance or instrumental ties or linkages that serves to promote continuity in a relationship. Furthermore, functional bonds are also described as task bonds ${ }^{50}$ created by the economic, strategic, technological (knowledge or information) and instrumental (productor service-related) benefits derived by the exchange parties.

\section{Social bonding tactics}

Social bonding tactics are personal ties or linkages forged during interaction at work. ${ }^{51}$ Researchers include the degree of personal friendship and liking shared by a buyer and seller, ${ }^{52}$ as well as linking of personal selves or identities through self disclosure; closeness; providing support or advice; being empathetic and responsive; feelings of affiliation, attachment or connectedness; and shared experiences. $^{53}$

Although the effects of 'social bonding tactics' can not yet replace 'price attraction', it provides customised service, developing independent relationships, making consumers trust and be satisfied with retailers' service, and understanding 
and learning consumers' needs and wants. Companies expressing friendship or gratitude with gifts to consumers really have social meaning. Personnel can use these kinds of socialising tactics to build stable relationships and promote relationship quality further.

\section{Structural bonding tactics}

Structural bonding tactics are knots relating to the structure, administration and institutionalisation of norms in a relationship. The rules, policies, procedures, infrastructure or agreements that provide formal structure to a relationship; the norms or routines that informally govern interaction; and the organisational systems and technologies that enable or facilitate interaction can provide psychological, legal and physical ties that bind parties to a relationship and make it difficult to consider other exchange partners. Here, this kind of bonding tactic means providing structural solving programmes for consumers; thus, marketing programmes with value-added advantages are provided by retailers.

By providing this level of relationship bonding tactics, companies can consolidate their relationship with consumers. The kinds of value-added services provided from structural integration are often technique related; they cannot only improve consumers' efficiency and productivity, but also are not easily emulated by competitors for heightened transforming costs. If further integrated with the previous two kinds of bonding tactics detailed above, it is not straightforward for competitors to penetrate into the company's existing markets.

\section{TRUST}

The development of trust is thought to be an important result of investing in dyadic buyer-seller relationships. ${ }^{54}$ As relationship efforts are defined as efforts that are actively provided by a retailer, the extent to which a retailer makes relationship efforts can provide evidence to the consumer that the retailer can be believed, cares for the relationship and is willing to make sacrifices. ${ }^{55,56}$ In the literature, several types of relationship efforts have been related to the concept of trust. Several authors indicate that more intense levels of buyer-seller communication enhance feelings of trust. ${ }^{57-60}$ Hence, it is possible to infer that trust was the main element required to develop high-level relationships, especially during the initial period of relationship development.

Trust has been discussed widely in channel literature. For example, Anderson and Weitz ${ }^{61}$ stated that the 'mutual trust of a relationship is strongly influenced by the level of communications in the dyad'. In the same way, a potential positive relationship between preferential treatment (social or structural efforts) and trust was indicated by Gwinner et al., ${ }^{62}$ who demonstrated that consumers perceive special treatment as a benefit resulting from their relationship with a seller. Finally, various marketing channel studies postulated that favourable financial outcomes reflect the partner's concern for the welfare of the channel member, and therefore increase the channel member's trust in the partner. ${ }^{63-65}$ As a result, a positive relationship between tangible rewards and trust can be hypothesised. Consequently, the following three hypotheses are formulated.

\footnotetext{
$\mathrm{H}_{1 \mathrm{a}}$ : A higher perceived level of financial bonding tactics leads to a higher level of trust.

$\mathrm{H}_{1 \mathrm{~b}}$ : A higher perceived level of social bonding tactics leads to a higher level of trust.
} 


\author{
$\mathrm{H}_{1 \mathrm{c}}$ : A higher perceived level of \\ structural bonding tactics leads to \\ a higher level of trust.
}

\section{COMMITMENT}

Commitment is generally regarded to be an important result of good relational interactions, Dwyer et al. suggested that commitment is 'fueled by the ongoing benefits accruing to each partner'. ${ }^{66}$ Morgan and Hunt's ${ }^{67}$ Commitment-Trust theory suggested that commitment and trust were the main variables that make relationship marketing successful.

Additionally, Moorman et al. ${ }^{68}$ suggested that consumers who are committed to a relationship might have a greater propensity to act because of their need to remain consistent with their commitment. In line with this, Bennett ${ }^{69}$ argues that the strength of consumers' commitment depends on their perceptions of efforts made by the seller. Furthermore, several authors have empirically investigated the relationship between relational performance, a construct that shows similarities to relationship investment, and relationship commitment. ${ }^{70-72}$

Thus, commitment was not only an important characteristic to maintain a good and long-term relationship, ${ }^{73,74}$ but also an expression of willingness that consumers want to stay with retailers. ${ }^{75-77}$ When the proportion of commitment becomes more remarkable, it is not difficult to infer that the relationship on both sides becomes more stable.

While relationships characterised by trust are so highly valued that parties will desire to commit themselves to such relationships, several authors indicate that trust positively affects commitment. ${ }^{78-81}$ In addition to conceptual support for a trust-commitment relationship, there exists strong empirical evidence for a positive path from trust to relationship commitment. ${ }^{82-86}$ According to De Wulf and Odekerken-Schroder, ${ }^{87}$ trust is hypothesised to affect relationship commitment as it is expected to generate the following benefits: (1) it reduces the perception of risk, (2) it increases the confidence of the buyer that short-term inequities will be resolved over a long period and (3) it reduces the transaction costs in an exchange relationship. These benefits should build attachment and create a desire to continue the relationship. ${ }^{88,89}$ The current study, however, is one of the few studies investigating the relationship between trust and relationship commitment in an information education services industry context. Therefore, the following hypothesis is investigated:

\section{$\mathrm{H}_{2}$ : A higher level of trust leads to a higher level of relationship commitment.}

\section{BEHAVIOURAL LOYALTY}

Hennig-Thurau and Klee ${ }^{90}$ suggested that relationship quality is an antecedent of repeat purchase behaviour. De Wulf et al. ${ }^{91}$ defined the construct of behavioural loyalty as a composite measure based on a consumer's purchasing frequency and amount spent at a retailer compared with the amount spent at other retailers from which the consumer buys. In other words, behavioural loyalty is measured as a unique combination of behavioural indicators, concordant with suggestions made by Sirohi et al. ${ }^{92}$ and Pritchard et al. ${ }^{93}$ Some empirical evidence has also been found for relationships between dimensions of relationship quality and behavioural loyalty. ${ }^{94-98}$

Having defined relationship commitment as 'a consumer's enduring desire to continue a relationship with a retailer accompanied by his willingness to make efforts at maintaining it', it is 
assumed that there exists a positive relationship between relationship commitment and behavioural loyalty as a desire and willingness to imply higher chances of actual behaviour. In addition to this, several authors support the notion that relationship commitment motivates buyers to act. ${ }^{99-101}$ Liljander and Strandvik ${ }^{102}$ concluded that commitment and behavioural loyalty are related concepts. Morgan and Hunt ${ }^{103}$ found significant relationships between the level of a buyer's relationship commitment and his acquiescence, propensity to leave and cooperation, all of which can be regarded as behavioural outcomes of relationships. Moorman et al. ${ }^{104}$ suggested that buyers who are committed to a relationship might have a greater propensity to act because of their need to remain consistent with their commitment. Finally, Dick and Basu ${ }^{105}$ stated that the stronger relationship commitment, the more likely the buyer is to overcome potential obstacles in the buyer-seller relationship, resulting in repeat patronage. Based on these insights, the following hypothesis is formulated:

\section{$\mathrm{H}_{3}$ : A higher level of relationship commitment leads to a higher level of behavioural loyalty.}

\section{METHODOLOGY}

\section{Study object and sample}

In order to observe the behavioural sequence of relationship efforts and relationship outcomes, the largest information education services institute in Taiwan, XYZ Company, which is anticipating going public in 2005, was chosen (market share: XYZ Company about 35 per cent, Secondary Information Education Services Institute about 15 per cent and others about 2-3 per cent). The sample, XYZ Company, founded in 1986, now has 600 employees, 100 professional lecturers, 500 part-time lecturers, more than 500,000 accumulated members, 94 directly owned branch stores and six value-added flagship stores. XYZ Company's main business items include computer education training, professional certification training, courses for groups of corporate users, web construct planning and online education courses. Online education courses focus on consumers whose learning time is limited, and this service is provided 24 hours a day, seven days a week.

With the assistance of XYZ Company, a total of 2,000 surveys were mailed randomly to the members of the company who had participated in at least one course during the time period from February to April 2002. A reminder letter was mailed approximately one week after the questionnaire had been sent out. To avoid demand effects, participants did not know the researcher personally. The respondents were guaranteed that all answers would be anonymous.

The final sample size was 933 , yielding a response rate of 46.7 per cent. The sampling method was successful in soliciting respondents with varied personal and firm characteristics. Respondents varied in sex (female, 54.4 per cent and male, 45.6 per cent), age ( $\leq 24$ years of age, 30 per cent; $25-36$ years of age, 55.6 per cent; and $\geq 37$ years of age, 14.4 per cent), education ( $\leq$ high school diploma, 2.4 per cent; senior high school, 14 per cent; university, 77 per cent; and graduate school, 6.6 per cent), and average monthly income $(\leq 25000$ NTD, 43.3 per cent; 25000-45000 NTD, 42.7 per cent, and $\geq 45000$ NTD, 14 per cent) finally, in the membership type included (platinum-card member, 91.5 per cent; member by hour, 4.2 per cent; member 
Table 1: Measurement model and confirmatory factor analysis: Exogenous constructs

\begin{tabular}{|c|c|c|c|}
\hline Exogenous construct & $\begin{array}{l}\text { Item-construct loading } \\
\text { standardised }\end{array}$ & $t$-value & Cronbach's alpha \\
\hline \multicolumn{4}{|c|}{ Financial bonding tactics } \\
\hline 1. FB1 & 0.82 & 24.54 & 0.7364 \\
\hline 2. FB2 & 0.71 & 21.43 & 0.7364 \\
\hline \multicolumn{4}{|l|}{ Social bonding tactics } \\
\hline 1. Social B1 & 0.81 & 28.79 & 0.8809 \\
\hline 2. Social B2 & 0.92 & 35.32 & 0.8809 \\
\hline 3. Social B3 & 0.91 & 34.57 & 0.8809 \\
\hline 4. Social B4 & 0.62 & 20.45 & 0.8809 \\
\hline \multicolumn{4}{|c|}{ Structural bonding tactics } \\
\hline 1. Structural B1 & 0.67 & 22.44 & 0.8558 \\
\hline 2. Structural B2 & 0.76 & 26.17 & 0.8558 \\
\hline 3. Structural B3 & 0.73 & 24.94 & 0.8558 \\
\hline 4. Structural B4 & 0.71 & 23.89 & 0.8558 \\
\hline 5. Structural B5 & 0.69 & 22.37 & 0.8558 \\
\hline 6. Structural B6 & 0.68 & 21.97 & 0.8558 \\
\hline
\end{tabular}

Table 2: Measurement model and confirmatory factor analysis: Endogenous constructs

\begin{tabular}{|c|c|c|c|}
\hline Endogenous construct & $\begin{array}{l}\text { Item-construct loading } \\
\text { standardised }\end{array}$ & $t$-value & Cronbach's alpha \\
\hline \multicolumn{4}{|l|}{ Trust } \\
\hline 1. Trust 1 & 0.88 & - & 0.9304 \\
\hline 2. Trust 2 & 0.90 & 45.16 & 0.9304 \\
\hline 3. Trust 3 & 0.90 & 35.50 & 0.9304 \\
\hline \multicolumn{4}{|l|}{ Commitment } \\
\hline 1. Commitment 1 & 0.59 & - & 0.8317 \\
\hline 2. Commitment 2 & 0.61 & 21.68 & 0.8317 \\
\hline 3. Commitment 3 & 0.67 & 17.81 & 0.8317 \\
\hline \multicolumn{4}{|l|}{ Consumer loyalty } \\
\hline 1. Loyal 1 & 0.76 & - & \\
\hline 2. Loyal 2 & 0.81 & 24.87 & 0.7563 \\
\hline 3. Loyal 3 & 0.61 & 15.44 & \\
\hline
\end{tabular}

by course, 2.7 per cent; and others, 1.6 per cent).

\section{Measures development}

The items related to all variables are included in Tables 1 and 2. Most measures represent a combination and synthesis of past formulations revealing comparable reliability scores (see Appendix). Self-administrated questionnaires were used for all measures. The independent variables of the research were relationship marketing efforts (including financial bonding, social bonding and structural bonding tactics, which are based on Berry and Parasuraman ${ }^{106}$ ). The dependent variable was consumer loyalty, which indicates consumers' specific attitudes. The intermediate variable, relationship quality, reflects the overall strength of relationship grade and consumers' degree of trust and commitment. All measures used for the constructs in the model are shown in Tables 1 and 2, and 5-point scales are used throughout the constructs.

\section{Data analysis method and data examination}

In the data examination process, cases incorporating missing values were deleted prior to data analysis. Next, the assumptions underlying the use of structural equation modelling were tested. 
Table 3: Goodness-of-fit statistics

\begin{tabular}{llllllllll}
\hline Model/construct & $\chi^{2}$ & $\chi^{2} / \mathbf{d f}$ & GFI & AGFI & RMSEA & RMR & SRMR & NNFI & CFI \\
\hline Exogenous & 319.22 & 6.26 & 0.95 & 0.92 & 0.075 & 0.051 & 0.047 & 0.98 & 0.98 \\
Endogenous & 207.19 & 8.60 & 0.95 & 0.91 & 0.090 & 0.040 & 0.053 & 0.97 & 0.98 \\
CFA-Overall & 402.33 & 2.61 & 0.96 & 0.94 & 0.042 & 0.030 & 0.032 & 0.99 & 0.99 \\
Sequential path model & 394.24 & 2.56 & 0.96 & 0.94 & 0.041 & 0.039 & 0.041 & 0.99 & 0.99 \\
\hline
\end{tabular}

With respect to sample size, it is generally accepted that the minimal sample size needed to ensure appropriate use of maximum likelihood estimation is 100-150. ${ }^{107}$ Larger sample sizes are required, however, in the case of model misspecification, model complexity, non-normality of data or the use of alternative estimation procedures. ${ }^{108}$ This study used somewhat larger sample sizes given the risk of moderate normality violations. Normality was tested by means of PRELIS2 based on the skewness and kurtosis of the observed variables. ${ }^{109}$ All of the samples revealed significant kurtosis and skewness $p$-values for most observed variables. Sample sizes were considered to be large enough to partially compensate for the existing kurtosis, however, reducing biases in parameter estimates. ${ }^{110}$ Finally, the study tested for the existence of univariate and multivariate outliers. The analyses revealed that almost no outliers were in existence.

Following Anderson and Gerbing's11 work, the structural equation models were tested using a two-stage structural equation model. First, Confirmatory Factor Analysis (CFA) was performed to evaluate construct validity regarding convergent and discriminate validity. In the second stage, path analysis was perform to test the research hypotheses empirically. The path-analytic procedure is becoming common in studies. ${ }^{112,113}$

\section{Overall model evaluation}

Table 3 reports the values of the fit statistics. The chi-squares are all significant $(p<0.05),{ }^{114}$ a finding not unusual with large sample sizes. ${ }^{115}$ The values for comparative fit index (CFI), non-normed fit index (NNFI), root mean square error of approximation (RMSEA) and standardised root mean residual (SRMR) are acceptably close to the standards suggested by $\mathrm{Hu}$ and Bentler: ${ }^{116,117} 0.95$ for CFI and NNFI, 0.06 for RMSEA and 0.08 for SRMR. Given that these batteries of overall goodness-of-fit indices were accurate and that the model was developed on theoretical bases, and given the high level of consistency across samples, no re-specifications of the model were made. This enabled the study to proceed in evaluating the measurement and structural models.

\section{Measurement model evaluation}

The quality and adequacy of the measurement models were assessed by investigating unidimensionality, convergent validity, reliability, discriminant validity and metric equivalence. First, unidimensionality was assessed on the basis of principal component analyses performed on all items. As all items loaded at 0.65 on the hypothesised factor and maximally at 0.30 on the other factors, it can be concluded that unidimensionality for each of the constructs was obtained. Secondly, convergent validity was supported as a result of the fact that the overall fit of the models was good, and that all loadings were highly statistically significant $(p<0.05) .{ }^{118,119}$ Thirdly, 
Table 4: Covariance matrix of latent variables

\begin{tabular}{lllllll}
\hline & Trust & Commitment & Loyalty & $\begin{array}{l}\text { Financial } \\
\text { bonding }\end{array}$ & $\begin{array}{l}\text { Social } \\
\text { bonding }\end{array}$ & $\begin{array}{l}\text { Structural } \\
\text { bonding }\end{array}$ \\
\hline Trust & 1 & & & & & \\
Commitment & 0.87 & 1 & & & & \\
Loyalty & 0.82 & 0.94 & 1 & & & \\
Financial bonding & 0.45 & 0.39 & 0.37 & 1 & 1 & 1 \\
Social bonding & 0.63 & 0.55 & 0.52 & 0.56 & 0.81 & 1 \\
Structural bonding & 0.68 & 0.59 & 0.56 & 0.71 & & \\
\hline
\end{tabular}

$n=933, \alpha=0.05$

Table 5: Empirical results of the proposed model

\begin{tabular}{llllll}
\hline Causal path & Hypothesis & $\begin{array}{l}\text { Expected } \\
\text { sign }\end{array}$ & $\begin{array}{l}\text { Path } \\
\text { coefficient }\end{array}$ & t-value & $\begin{array}{l}\text { Assessment } \\
(\mathbf{p} \leq \mathbf{0 . 0 5})\end{array}$ \\
\hline Financial bonding $\rightarrow$ Trust & H 1a & + & -0.07 & -1.33 & $\mathrm{~ns}$ \\
Social bonding $\rightarrow$ Trust & H 1b & + & 0.24 & 4.15 & $\mathrm{~s}$ \\
Structural bonding $\rightarrow$ Trust & H 1C & + & 0.54 & 6.98 & $\mathrm{~s}$ \\
Trust $\rightarrow$ Commitment & H 2 & + & 0.87 & 16.20 & $\mathrm{~s}$ \\
Commitment $\rightarrow$ Loyalty & H 3 & + & 0.97 & 15.02 & $\mathrm{~s}$ \\
\hline
\end{tabular}

Note: $\chi_{(154)}^{2}=397.24, p=0.0000, \mathrm{RMSEA}=0.041 ; \mathrm{GFI}=0.96, \mathrm{AGFI}=0.94 ; \mathrm{CFI}=0.99 ; \mathrm{NFI}=0.99 ; \mathrm{NNFI}=0.99$

reliability was supported as a result of the fact that all Cronbach alpha values exceeded 0.70, indicating acceptable reliability levels. ${ }^{120}$ Moreover, as can be derived from Table 3 , all of the composite reliability measures were above 0.60, corresponding to Bagozzi and Yi's ${ }^{121}$ minimum values of 0.60 . As a result, it can be concluded that all constructs yielded satisfactory reliabilities.

Fourthly, CFAs were used to test the adequacy of the measurement model. Separate CFAs were used for relationship efforts (financial bonding, social bonding and structural bonding) and relationship behavioural sequence (trust, commitment and behavioural loyalty) (see Table 4). The proposed measurement model was estimated using LISREL 8.52. ${ }^{122,123}$ The results indicate reasonable overall fits between the model and the observed data, as is shown in Table 3, for the relationship efforts construct CFA model, the relationship outcomes construct CFA model, and even the full model fit of measurement model (GFI), are all higher than $0.90 .{ }^{124}$ Additionally, NNFI and
CFI greatly exceed the recommended 0.90 threshold levels. ${ }^{125-127}$ These results, again, demonstrated that the data reasonably, again, fit the model.

\section{Path model and hypothesis testing}

Table 5 presents the assessment of overall model fit and the tests of research hypotheses. For the conceptual model, the estimated structural paths are represented in Figure 2, which shows the hypothesised relationships between latent constructs and their corresponding standardised path coefficients. In the conceptual model, significant path coefficients are thick-lined in each figure and all significant relationships between latent constructs are in the hypothesised direction. This provides strong evidence for the conceptual model and its related hypotheses. A second evaluation of the structural model is related to testing each of the hypotheses previously formulated. In the empirical results, social and structural bonding tactics consistently led to trust, which positively affected 


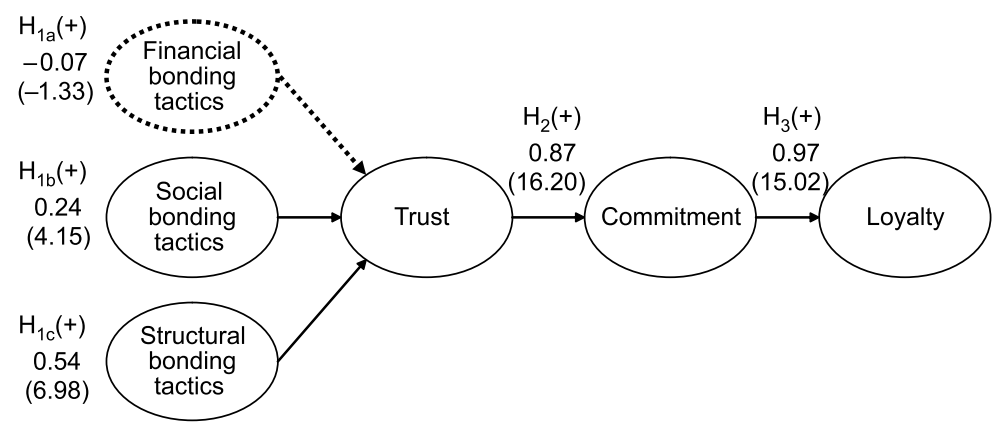

Note: Numbers in parenthesis are $t$-values, others are standardised path coefficients

Figure 2 Results of hypothesised framework

relationship commitment, ultimately influencing a consumer's behavioural loyalty (support for $\mathrm{H}_{1 \mathrm{~b}}, \mathrm{H}_{1 \mathrm{c}}, \mathrm{H}_{2}$ and $\left.\mathrm{H}_{3}\right)$.

\section{DISCUSSIONS AND IMPLICATIONS}

$\mathrm{XYZ}$ Company is the largest information education services company in Taiwan.

With the current internet era, companies in the information education services industry face an unprecedented challenge. Reichheld and Sasser ${ }^{128}$ suggest that consumers who remain with a firm for a period of years because they are pleased with the service they receive are more likely than short-term consumers to buy additional services and spread favourable word-of-mouth communication.

\section{Both unidirectional and interactive social bonding tactics have the greatest effects on trust}

According to the empirical results, all of the relationship-marketing efforts have positive effects on trust except for financial bonding tactics in the information education services industry. As for the most powerful relationship bonding tactics, social bonding tactics show that companies should stress direct mailing, courteousness, personal conversation, and taking care of members' needs and welfare. Regarding structural bonding tactics, results show that infra-structural establishment, active course-planning services and immediate complaint solving are important structural bonding items. Additionally, diversified alliances to provide various services, providing new services in accordance with consumers' needs and market conditions are also inevitable.

\section{A concern of relationship efforts to relationship outcomes}

In terms of endogenous constructs, the results clearly reveal a significant relationship between the construct of trust and the construct of relationship commitment, indicating that trust is important in the consumer situation. This implies that the greater the consumer's trust, the higher their relationship commitment will be; that is, consumers will only be committed to a relationship with a retailer when they have trust in this retailer. Therefore, consumer relationship management is indeed a critical dimension for consumers' trust and relationship commitment in the information education services industry. In other words, one could infer that once consumers feel trust with a retailer's 
relationship efforts, their commitment to that retailer becomes stronger.

Regarding the correlation between relationship commitment and behavioural loyalty, the results show that consumers' relationship commitment to retailers has positive effects on consumers' behavioural loyalty. Therefore, one could reason that the greater the consumers' relationship commitment is to the retailer, the more consumers will demonstrate their loyalty. Consequently, researchers should be aware of the fact that, while relationship commitment is often regarded as the ultimate relationship outcome, it is only an antecedent of behavioural loyalty.

From the survey results discussed above, one could infer that it is not only an institution's service depth and scope itself, but also the provision of structural resolutions or value-added services that comprise the most effective relationship marketing programmes. Furthermore, once consumers perceive higher relationship efforts or feel trust in a company's relationship efforts, they will make a greater commitment to that retailer. Finally, consumers will feel obligated to demonstrate their loyalty by remaining with the retailer.

\section{CONTRIBUTIONS AND MANAGERIAL IMPLICATIONS}

With the brand new industry, XYZ Company will be the shining star of the information education services industry in Taiwan for the foreseeable future. From the conclusions stated above, one could infer that without knowing why consumers buy what a company sells, targeted investment to improve consumer satisfaction will be a waste of money. Managers should treat consumers as partners in their provision of original services or in their quest for successful new services, while reciprocation of behaviour will foster a positive atmosphere, remove barriers of risk and enable relationships to move forward.

This study was aimed at investigating the potential role of a retailer's relationship efforts in influencing consumer attitudes and behaviour. To the authors' knowledge, it is the first study that demonstrates the effect of relationship efforts on trust in the information education services setting. In the samples presented here, the results indicate that retailers can influence consumer trust by rewarding consumers for their patronage to the retailer.

While the development and sustainability of loyalty is increasingly difficult to achieve today and is still surrounded by ambiguity regarding its underlying determinants, it is believed that the research makes a significant contribution to relationship marketing theory in two unique and different ways. First, the model contributes to the existing literature by specifying how information education services providers can guide consumer perceptions of the relationship efforts by applying at least three different and specific relationship bonding tactics. Prior studies have rarely investigated the role of such tactics in shaping consumer relationships. Secondly, the study demonstrates why information education services providers benefit from investing in consumer relationships by assessing the impact of relationship efforts on relationship outcomes and ultimately on consumer behavioural loyalty. These two research questions were tested comprehensively and rigorously by replicating the study within a newly established information services institution.

With respect to the research outcomes, relationship-marketing efforts were found to play a differential, yet consistently positive role in affecting consumers' relationship outcomes. Today's 
information education services providers increasingly offer comparable merchandise, copy competitors' price promotions, share common distribution systems and treat consumers well in terms of services offered; thus, increased opportunities can be derived from this study's results to direct greater attention to developing and implementing relationship bonding tactics.

Another research portion of this study assessed the effect of trust on relationship commitment and, ultimately, behavioural loyalty. Trust was expected to play an important role in determining relationship commitment, and that assumption was confirmed in the samples. The path from relationship commitment to behavioural loyalty was also demonstrated to have a positively significant effect, supporting the findings of Bagozzi ${ }^{129}$ and Kang and Ridgway, ${ }^{130}$ who argued that consumers feel obligated to reciprocate a retailer's investments in the retailer-consumer relationship by increasing their loyalty to that retailer. This finding implies that it pays for retailers to invest in consumer relationships, because such increased consumer relationship will result in increased loyalty.

\section{Limitations and directions for further research}

Some limitations might be related to collecting the data and interpreting the results. First, the variables of the research are measured by a Likert 5-point scale, in which the deviations of each point are hypothesised to be equal - but this is not true. A second potential limitation is related to the measurement of behavioural loyalty. The true meaning of behavioural loyalty may be only partially captured given that its measure was based on self-reports. Data bank information could be used as input for measuring actual purchasing behaviour. ${ }^{131}$ The confidence in the results could be strengthened with the use of behavioural data on consumer purchase histories that are not subject to potential recall loss. Additionally, other important variables may have been omitted. For example, additional tangible elements in the company's services mix (such as pricing and promotion, services quality and assortment) could be added as antecedents of trust or commitment. This is evidenced by the fact that the percentage of explained variance of trust could still be improved.

Furthermore, it is likely that the relative importance of relationship efforts in determining relationship investment varies according to the length of a relationship or the extent of product involvement. It could be assumed that the longer a relationship exists, the stronger the relative impact of relationship bonding tactics on trust or commitment will be compared with product and service tactics, and the effects of extent of product involvement. Finally, the model is empirically tested in a Taiwanese sample. As is well established, culture plays a significant role in relationship marketing systems.

Therefore, follow-up research could choose different industries or the whole information education services industry. Additionally, as the internet-based e-commerce industry is different from physical companies, researchers could discuss the differences of relationship marketing patterns between physical industries and virtual industries. These recognised shortcomings and recommendations could inspire researchers to define their future research agendas.

\section{References}

1 Dawkins, P. and Reichheld, F. (1990) 'Customer retention as a competitive weapon', Directors and Boards, Vol. 14, pp. 42-47. 
2 Parasuraman, A., Berry, L. L. and Zeithaml, V. A. (1985) 'A conceptual model of service quality and its implications for future research', Journal of Marketing, Vol. 49, No. 4, pp. 41-50.

3 Reichheld, F. and Sasser, W. E., Jr (1990) 'Zero defections: Quality comes to services', Harvard Business Review, Vol. 68, No. 5, pp. 105-111.

4 Zeithaml, V. A., Parasuraman, A. and Berry, L. L. (1990) 'Delivering Quality Service: Balancing Customer Perceptions and Expectations', The Free Press, New York, NY.

5 Berry, L. L. and Gresham, L. G. B. (1986) 'Relationship retailing: Transforming customers into clients', Business Horizons, Vol. 29, No. 6, pp. 43-48.

6 Ghosh, B. C. and Ling, M. T. (1994) 'Total quality management in services: The case of Singapore's advertising industry', The TQM Magazine, Vol. 6, No. 4, pp. 34-41.

7 Morgan, R. M. and Hunt, S. D. (1994) 'The commitment-trust theory of relationship marketing', Journal of Marketing, Vol. 58, No. 3, pp. 20-38.

8 Parasuraman, A., Berry, L. L. and Zeithaml, V. A. (1988) 'SERVQUAL: A multiple item scale for measuring consumer perceptions of service quality', Journal of Retailing, Vol. 64, No. 1, pp. 12-40.

9 Woodruff, R. B. (1997) 'Customer value: The next source for competitive advantage', Journal of the Academy of Marketing Science, Vol. 25, No. 2, pp. 139-153.

10 Beatty, S. E., Coleman, J. E., Reynolds, K. E. and Lee, J. (1996) 'Customer-sales associate retail relationships', Journal of Retailing, Vol. 72, No. 3, pp. 223-247.

11 Bendapudi, N. and Berry, L. L. (1997) 'Customers' motivations for maintaining relationships with service providers', Journal of Retailing, Vol. 73, pp. 15-37.

12 Bitner, M. J. (1995) 'Building service relationships: It's all about promises', Journal of the Academy of Marketing Science, Vol. 23, No. 4, pp. 246-251.

13 O'Malley, L. and Tynan, C. (2000) 'Relationship marketing in consumer markets: Rhetoric or reality?' European Journal of Marketing, Vol. 34, No. 7, pp. 797-815.

14 Bolton, R. N. and Drew, J. H. (1991) 'A multistage model of customers' assessments of service quality and value', Journal of Consumer Research, Vol. 17, No. 4, pp. 375-384.

15 Frenzen, J. K. and Davis, H. L. (1990) 'Purchasing behavior in embedded markets', Journal of Consumer Research, Vol. 17, No. 1, pp. 1-12.

16 Gwinner, K. P., Gremler, D. D. and Bitner, M. J. (1998) 'Relational benefits in services industries: The customer's perspective', Journal of the Academy of Marketing Science, Vol. 26, No. 2, pp. 101-114.

17 Hennig-Thurau, T. and Klee, A. (1997) 'The impact of customer satisfaction and relationship quality and customer retention: A critical reassessment and model development', Psychology and Marketing, Vol. 14, No. 8, pp. 737-764.

18 Berry, L. L. and Thompson, T. W. (1982)

'Relationship banking: The art of turning customers into clients', Journal of Retail Banking, Vol. 4, No. 2, pp. 64-73.

19 Day, A. (1985) 'Selling to the corporate customers', International Journal of Bank marketing, Vol. 3, No. 4, pp. 60-70.

20 Moriarty, R. T., Kimball, R. C. and Gay, J. H. (1983) 'The management of corporate banking relationships', Sloan Management Review, Vol. 24, No. 3, pp. 3-16.

21 Kimball, R. C. (1990) 'Relationship versus product in retail banking', Journal of Retail Banking, Vol. 12, No. 1, pp. 13-25.

22 Crosby, L. A., Evans, K. R. and Cowles, D. (1990) 'Relationship quality in services selling: An interpersonal influence perspective', Journal of Marketing, Vol. 54, No. 3, pp. 68-81.

23 Juttner, U. and Wehrli, H. P. (1994) 'Relationship marketing from a value system perspective', International Journal of Service Industry Management, Vol. 5, No. 5, pp. 54-73.

24 Gwinner et al. (1998) op. cit.

25 Bhattacharya, C. B., Rao, H. and Glynn, M. A. (1995) 'Understanding the bond of identification: An investigation of its correlates among art museum members', Journal of Marketing, Vol. 59, No. 4, pp. 46-57.

26 Wray, B., Palmer, A. and Bejou, D. (1994) 'Using neural network analysis to evaluate buyer-seller relationships', European Journal of Marketing, Vol. 28, No. 10 , pp. 32-48.

27 De Wulf, K. and Odekerken-Schroder, G. (2003) 'Accessing the impact of a retailer's relationship efforts on consumers' attitude and behavior', Journal of Retailing and Consumer Services, Vol. 10, No. 2, pp. 95-108.

28 Gwinner et al. (1998) op. cit.

29 De Wulf and Odekerken-Schroder (2003) op. cit.

30 Fontenot, R. and Wilson, E. J. (1997) 'Relational exchange: A review of selected models for a prediction matrix of relationship activities', Journal of Business Research, Vol. 39, No. 1, pp. 5-12.

31 Frenzen and Davis (1990) op. cit.

32 Parasuraman, A., Berry, L. L. and Zeithaml, V. A. (1994) 'Reassessment of expectations as a comparison standard in measuring service quality: Implications for further research', Journal of Marketing, Vol. 58, No. 1, pp. 111-124.

33 Storbacka, K., Strandvik, T. and Gronroos, C. (1994) 'Managing customer relationships for profit: The dynamics of relationship quality', International Journal of Service Industry Management, Vol. 5, No. 5, pp. 21-38.

34 Dwyer, F. R., Schurr, P. H. and Oh, S. (1987) 'Developing buyer-seller relationships', Journal of Marketing, Vol. 51, No. 2, pp. 11-27.

35 Parasuraman, A. (1997) 'Reflections on gaining competitive advantage through customer value', Journal of the Academy of Marketing Science, Vol. 25, No. 2, pp. 154-161.

36 Gwinner et al. (1998) op. cit. 37 De Wulf and Odekerken-Schroder (2003) op. cit. 38 De Wulf, K. Odekerken-Schroder, G. and 
Iacobucci, D. (2001) 'Investments in consumer relationships: A cross-country and cross-industry exploration', Journal of Marketing, Vol. 65, No. 4, pp. 33-50.

39 McCall, G. J. (1970) 'The social organization of relationships', in McCall, G. J. et al. (eds) 'Social Relationships', Aldine Publishing Company, Chicago, IL, pp. 3-34.

40 Turner, R. H. (1970) 'Family Interaction', John Wiley, New York, NY.

41 Fontenot and Wilson (1997) op. cit.

42 Han, S. (1992) 'Antecedents of buyer-seller long-term relationships: An exploratory model of structural bonding and social bonding', (Working Paper No. 6-1992). Institute for the Study of Business Markets, Pennsylvania State University, University Park, PA.

43 Smith, J. B. (1998) 'Buyer-seller relationships: Similarity, relationship management, and quality', Psychology and Marketing, Vol. 15, No. 1, pp. 3-21.

44 De Wulf et al. (2001) op. cit.

45 Berry, L. L. and Parasuraman, A. (1991) 'Marketing Services: Competing Through Quality', The Free Press, New York, NY.

46 Williams, J. D., Han, S. L. and Qualls, W. J. (1998) 'A conceptual model and study of cross-cultural business relationships', Journal of Business Research, Vol. 42, No. 2, pp. 135-143.

47 Armstrong, G. and Kolter, P. (2000) 'Marketing: An Introduction', 5th edn, Prentice Hall, Englewood Cliffs, NJ.

48 Berry and Parasuraman (1991) op. cit. The word 'bonding' refers more to an on-going process, and 'bonds' to a relationship that has already been established. This paper uses the term 'relationship bonding' in place of 'relational bonds' or others, meaning an on-going marketing process.

49 Smith (1998) op. cit.

50 Turner (1970) op. cit.

51 Ibid.

52 Fontenot and Wilson (1997) op. cit.

53 Turner (1970) op. cit.

54 Gundlach, G. T., Achrol, R. S. and Mentzer, J. T. (1995) 'The structure of commitment in exchange', Journal of Marketing, Vol. 59, No. 1, pp. 78-92.

55 Doney, P. M. and Cannon, J. P. (1997) 'An examination of the nature of trust in buyer-seller relationships', Journal of Marketing, Vol. 61, No. 2, pp. 35-51.

56 Ganesan, S. (1994) 'Determinants of long-term orientation in buyer-seller relationships', Journal of Marketing, Vol. 58, No. 2, pp. 1-19.

57 Bendapudi and Berry (1997) op. cit.

58 Bhattacharya et al. (1995) op. cit.

59 Doney and Cannon (1997) op. cit.

60 Anderson, J. C. and Narus, J. A. (1990) 'A model of distributor firm and manufacturer firm working relationships', Journal of Marketing, Vol. 54, No. 1, pp. $42-58$.

61 Anderson, E. and Weitz, B. (1989) 'Determinants of continuity in conventional industrial channel dyads', Marketing Science, Vol. 8, No. 4, pp. 310-323.
62 Gwinner et al. (1998) op. cit.

63 Ganesan (1994) op. cit.

64 Geyskens, I. (1998) 'Trust, satisfaction, and equity in marketing channel relationships', Doctoral dissertation, Catholic University of Louvain, Belgium.

65 Scheer, L. and Stern, L. (1992) 'The effect of influence type and performance outcomes on attitude toward the influencer', Journal of Marketing Research, Vol. 29, No. 1, pp. 128-142.

66 Dwyer et al. (1987) op. cit.

67 Morgan and Hunt (1994) op. cit.

68 Moorman, C., Desphande, R. and Zaltman, G. (1993) 'Factors affecting trust in market research relationships', Journal of Marketing, Vol. 57, No. 1, pp. 81-101.

69 Bennett, R. (1996) 'Relationship formation and governance in consumer markets: Transactional versus the behaviourist approach', Journal of Marketing Management, Vol. 12, No. 5, pp. 417-436.

70 Morgan and Hunt (1994) op. cit.

71 Weitz, B. A. and Bradford, K. D. (1999) 'Personal selling and sales management: A relationship marketing perspective', Journal of the Academy of Marketing Science, Vol. 27, No. 2, pp. 241-254.

72 Baker, T. L., Simpson, P. M. and Siguaw, J. A. (1999) 'The impact of suppliers' perceptions of reseller market orientation on key relationship constructs', Journal of the Academy of Marketing Science, Vol. 27, No. 1, pp. 50-57.

73 Hennig-Thurau and Klee (1997) op. cit.

74 Macintosh, G. and Lockshin, L. S. (1997) 'Retail relationships and store loyalty: A multi-level perspective', International Journal of Research in Marketing, Vol. 14, No. 5, pp. 487-497.

75 De Wulf et al. (2001) op. cit.

76 Moorman et al. (1993) op. cit.

77 Odekerken-Schroder, G., De Wulf, K. and Schumacher, P. (2003) 'Strengthening outcomes of retailer-consumer relationships — The dual impact of relationship marketing tactics and consumer personality', Journal of Business Research, Vol. 56, No. 3, pp. 177-190.

78 Beatty et al. (1996) op. cit.

79 Gundlach, G. T. and Murphy, P. E. (1993) 'Ethical and legal foundations of relational marketing exchanges', Journal of Marketing, Vol. 57, No. 4, pp. 35-46.

80 Ramsey, R. P. and Sohi, R. S. (1997) 'Listening to your customers: The impact of perceived salesperson listening behavior on relationship outcomes', Journal of the Academy of Marketing Science, Vol. 25, No. 2, pp. $127-137$.

81 Schurr, P. H. and Ozanne, J. L. (1985) 'Influences on exchange processes: Buyers' preconceptions of a seller's trustworthiness and bargaining toughness', Journal of Consumer Research, Vol. 11, No. 4, pp. 939-953.

82 Morgan and Hunt (1994) op. cit.

83 Doney and Cannon (1997) op. cit.

84 Ganesan, S. (1994) op. cit.

85 Macintosh and Lockshin (1997) op. cit. 
86 Andaleeb, S. S. (1996) 'An experimental investigation of satisfaction and commitment in marketing channels: The role of trust and dependence', Journal of Retailing, Vol. 72, No. 1, pp. 77-93.

87 De Wulf and Odekerken-Schroder (2003) op. cit.

88 Ganesan (1994) op. cit.

89 Andaleeb (1996) op. cit.

90 Hennig-Thurau and Klee (1997) op. cit.

91 De Wulf et al. (2001) op. cit.

92 Sirohi, N., McLaughlin, E. W. and Wittink, D. R. (1998) 'A model of consumer perceptions and store loyalty intentions for a supermarket retailer', Journal of Retailing, Vol. 74, No. 2, pp. 223-245.

93 Pritchard, M. P., Havitz, M. E. and Howard, D. R. (1999) 'Analyzing the commitment-loyalty link in service contexts', Journal of the Academy of Marketing Science, Vol. 27, No. 3, pp. 333-348.

94 Macintosh and Lockshin (1997) op. cit.

95 Bolton, R. N. (1998) 'A dynamic model of the duration of the customer's relationship with a continuous service provider: The role of satisfaction', Marketing Science, Vol. 17, No. 1, pp. 45-65.

96 Dick, A. S. and Basu, K. (1994) 'Customer loyalty: Toward an integrated conceptual framework', Journal of the Academy of Marketing Science, Vol. 22, No. 2, pp. 99-113.

97 Heskett, J. L., Jones, T. O., Loveman, G. W. et al. (1994) 'Putting the service profit chain to work', Harvard Business Review, Vol. 72, No. 2, pp. 164-174.

98 Bowen, J. T. and Shoemaker, S. (1998) 'Loyalty: A strategic commitment', Cornell Hotel and Restaurant Administration Quarterly, Vol. 39, No. 1, pp. 12-25.

99 Hennig-Thurau and Klee (1997) op. cit.

100 Gruen, T. W. (1995) 'The outcome set of relationship marketing in consumer markets', International Business Review, Vol. 4, pp. 447-469.

101 Mathieu, J. E. and Zajac, D. M. (1990) 'A review and meta-analysis of the antecedents, correlates, and consequences of organizational commitment', Psychological Bulletin, Vol. 108, No. 2, pp. 171-194.

102 Liljander, V. and Strandvik, T. (1993) 'Estimating zones of tolerance in perceived service quality and perceived service value', International Journal of Service Industry Management, Vol. 4, No. 2, pp. 6-28.

103 Morgan and Hunt (1994) op. cit.

104 Moorman et al. (1992) op. cit.

105 Dick and Basu (1994) op. cit.

106 Berry and Parasuraman (1991) op. cit.

107 Anderson, J. C. and Gerbing, D. W. (1988) 'Structural equation modeling in practice: A review and recommended two-step approach', Psychological Bulletin, Vol. 103, No. 3. p. 411.

108 Hair, J. F., Anderson, R. E., Tatham, R. L. and Black, W. C. (1998) 'Multivariate Data Analysis', Prentice-Hall, Upper Saddle River, NJ.

109 Bollen, K. A. (1989) 'Structural Equations With
Latent Variables', John Wiley and Son, New York, NY.

110 Hair et al. (1998) op. cit.

111 Anderson and Gerbing (1988) op. cit.

$112 \mathrm{Li}, \mathrm{T}$. and Calantone, R. J. (1998). 'The impact of market knowledge competence on new product advantage: Conceptualization and empirical examination', Journal of Marketing, Vol. 62, No. 4, pp. 13-29.

113 Chaudhuri, A. and Holbrook, M. B. (2001) 'The chain of effects from brand trust and brand affect to brand performance: The role of brand loyalty', Journal of Marketing, Vol. 65, No. 2, pp. 83-93.

114 Bollen (1989) op. cit.

115 Doney and Cannon (1997) op. cit.

$116 \mathrm{Hu}$, L.-T. and Bentler, P. M. (1995). 'Evaluating model fit', in Hoyle, R. H. (ed.) 'Structural Equation Modeling', Sage Publications, Thousand Oaks, CA, pp. 76-99.

117 Hu, L.-T. and Bentler, P. M. (1999) 'Cut-off criteria for fit indexes in covariance structure analysis: Conventional criteria versus new alternatives', Structural Equation Modeling, Vol. 6, No. 1, pp. 1-55.

118 Hildebrandt, L. (1987) 'Consumer retail satisfaction in rural areas: A reanalysis of survey data', Journal of Economic Psychology, Vol. 8, No. 1, pp. 19-42.

119 Steenkamp, J.-B. E. M. and van Trijp, H. C. M. (1991) 'The use of LISREL in validating marketing constructs', International Journal of Research in Marketing, Vol. 8, No. 4, pp. 283-299.

120 Nunnally, J. C. (1978). 'Psychometric Theory', 2nd edn McGraw-Hill, New York, NY.

121 Bagozzi, R. P. and Yi, Y. (1988) 'On the evaluation of structural equation models', Journal of the Academy of Marketing Science, Vol. 16, No. 1, pp. 74-94.

122 Joreskog, K, and Sorborn, D. (1989) 'LISREL 7: User's Reference Guide', Scientific Software, Mooresville, IN.

123 Joreskog, K. and Sorborn, D. (1993) 'LISREL 8: Manual', Scientific Software, Mooresville, IN.

124 Bagozzi and Yi (1988) op. cit.

125 Bollen, K. A. (1989) op. cit.

$126 \mathrm{Hu}$ and Bentler (1995) op. cit.

127 Hoyle, R. H. and Panter, A. T. (1995) 'Writing about structural equation modeling', in 'Structural Equation Modeling', Hoyle, R. H. (ed.) Sage Publications, Thousand Oaks, CA, pp. 158-176.

128 Reichheld and Sasser (1990) op. cit.

129 Bagozzi, R. P. (1995) 'Reflections on relationship marketing in consumer markets', Journal of the Academy of Marketing Science, Vol. 23, No. 4, pp. 272-277.

130 Kang, Y.-S. and Ridgway, N. M. (1996) 'The importance of consumer market interactions as a form of social support for elderly consumers', Journal of Public Policy and Marketing, Vol. 15, No. 1, pp. 108-117.

131 De Wulf et al. (2001), op. cit. 


\section{APPENDIX}

\begin{tabular}{ll}
\hline Construct & Source \\
\hline Relationship bonding & McCall, 1970; Turner, 1970; Han, 1992; Wilson, 1995; Smith, 1998; Berry and \\
& Parasuraman, 1991; William, Hans and Qualls, 1998; Armstrong and Kolter, \\
& 2000; Peltier and Westfall, 2000 \\
Financial bonding & Smith, 1998; Turner, 1970 \\
Social bonding & Turner, 1970; Wilson, 1995 \\
Structural bonding & Developed for this study \\
Trust & Doney and Cannon, 1997; Geyskens et al., 1996; Moorman et al., 1992; Morgan \\
& and Hunt, 1994; De Wulf et al., 2001; Odekerken-Schroderet et al., 2003; Gundlach, \\
& Achrol and Mentzer, 1995; Garbarino and Johnson, 1999 \\
Commitment & Dwyer et al., 1987; Bennett, 1996; Moorman et al., 1992; Morgan and Hunt, \\
& 1994; Weitz and Kevin, 1999; Baker, Simpson, and Siguaw, 1999 \\
& Hennig-Thurau and Klee, 1997; Macintosh and Lockshin, 1997; De Wulf et al., \\
& 2001; Odekerken-Schroder et al., 2003 \\
& Sirohi et al., 1998; Macintosh and Lockshin, 1997; Pritchard, Havitz and \\
& Howard, 1999; Bolton, 1998; Dick and Basu, 1994; Heskett et al., 1994; \\
Behavioural loyalty & Bowen and Shoemaker, 1998; Rust, Zahorik and Keiningham, 1995; Zeithaml, \\
& Berry, and Parasuraman 1996 \\
\hline
\end{tabular}

